\title{
Exchange Rate Volatility And Non-Oil Imports In Nigeria: A Cointegration Analysis
}

\author{
Uduakobong S. Inam, Ph.D \\ Department of Economics, Faculty of Social Sciences \\ University of Uyo, Uyo, Akwa Ibom State, Nigeria \\ Williams Anthony Oscar \\ Department of Economics, Faculty of Social Sciences \\ University of Uyo, Uyo, Akwa Ibom State, Nigeria
}

\begin{abstract}
This paper analyses the relationship between exchange rate volatility and non-oil imports in Nigeria using annual data covering the period of 1970 to 2015. Specifically, it seeks to: investigate the existence of a long run relationship between exchange rate volatility and non-oil imports in Nigeria; and determine the nature of the causal relationships between exchange rate volatility and non-oil imports in Nigeria. The study employed the Johansen test of Cointegration, Error Correction Model, and the Granger Causality test to achieve the objectives. The findings reveal that: there exists a long run relationship between exchange rate volatility and non-oil import,; exchange rate does not granger cause the movements in non-oil imports. The study recommends amongst others that the exchange rate should be closely monitored and effectively managed. Specifically, policies that seek to maintain the exchange rate at a very minimal level should be promoted. The government and relevant monetary authorities should seek to employ and implement policies that stabilize the exchange rate given its significant impact on non-oil imports in Nigeria.
\end{abstract}

Keywords: Exchange Rate, Non-Oil Imports, Cointegration, Causality, Nigeria.

\section{INTRODUCTION}

Exchange rate stability is a major macroeconomic objective of countries in the global economy. Its critical role in the attainment of macroeconomic stability in both the developed and developing economies hinges greatly on its importance as a price that not only affects the price of imports, exports, and by extension, the balance of payments, but also the general price level. Consequently, governments and relevant authorities all over the world employ the Exchange rate as a policy tool to manage the volume of imports and exports as well as the general price level in a country.

Exchange rate which is the price of one currency in relation to another, in a slightly different perspective, expresses a national currency's quotation with respect to foreign ones. On the other hand, imports are goods or services brought into one country from another. Countries are most likely to import goods that domestic industries cannot produce as efficiently or cheaply. They may also import raw materials or commodities that are not available within its borders but are required in industries for the production of finished goods and services. On the contrary, exports are goods or services sold out to foreign countries.

Imports and exports exert a profound influence on the consumer and the economy. These imports, provide more choices to consumers. But when there is too much import in relation to 
exports it can distort a nation's balance of trade and devalue its currency. However, imports are a vital component of the economy. A high level of imports indicates robust domestic demand and a growing economy. From the literature, one of the key determinants of the volume and cost of imports is the exchange rate. Thus variations in exchange rate is usually of great concern to importers and consumers of imported raw materials and finished goods.

Nigeria is a developing country, whose imports are highly dominated with consumer goods. This may be due to the poor infrastructure, low level of technology and a high cost of business operation which are very detrimental to the manufacturers whose activities would boost the level of exports that in the long run boost economic growth and cause the exchange rate to appreciate. However, since the major components of imports in Nigeria as at 2015 were base metals, machinery and mechanical appliances, electrical equipment, vehicles, aircraft vessels and associated transport equipment which constitute $47.8 \%$ of the total expenditure on imports (Central bank of Nigeria Statistical Bulletin, 2015) which could in the long run promote local production.

Over the years, exchange rate volatility has been a topical issue amongst policy makers on account of the vital role an optimal and sustainable exchange rate plays in the achievement of sustainable economic growth and development. Olisadebe (1991) blamed the volatility of the Nigerian exchange rate on the continuous existence of parallel markets in the country. This means that the continuous increase in exchange rate volatility is believed to have adverse effect on key sectors of the economy. In the same vein, Ahmad and Zarma (1997) argued that "the deregulation of the foreign exchange market in the face of serious supply constraints and government interference caused serious fluctuations in the exchange rate for the naira".

The impact of the exchange rate volatility on imports and exports flows especially in developing countries like Nigeria have been described as one of the main sources of economic instability and uncertainty. The unexpected swings in the exchange rate of the naira have been identified as enormous and volatile. Consequent upon this swing, monetary authorities in Nigeria and other developing countries have developed close trade ties with the developed nations for intervention. This, in some cases averts severe currency misalignment and volatility which in turn produces payment imbalances responsible for economic distortions and inevitably sharp currency reversals. (Adeoye and Atanda, 2010).

Figure 1 presents the graphical trend of real exchange rate and non-oil imports in Nigeria from 1970-2015. The trend of exchange rate and non-oil imports shows that there is no trace of a correlation between the two variables. Is there any long run relationship between exchange rate and non-oil imports in Nigeria? Does causal relations exist between both variables? What is the nature and direction of causality between exchange rate and non-oil imports in Nigeria? These are the questions which this study seeks to answer. Thus the major objective of this study is to analyse the relationship between exchange rate volatility and non-oil imports in Nigeria using annual data covering the period of 1970 to 2015. Specifically, it seeks to: investigate the existence of a long run relationship between exchange rate volatility and nonoil imports in Nigeria; and determine the nature of the causal relationships between exchange rate volatility and non-oil imports in Nigeria. 


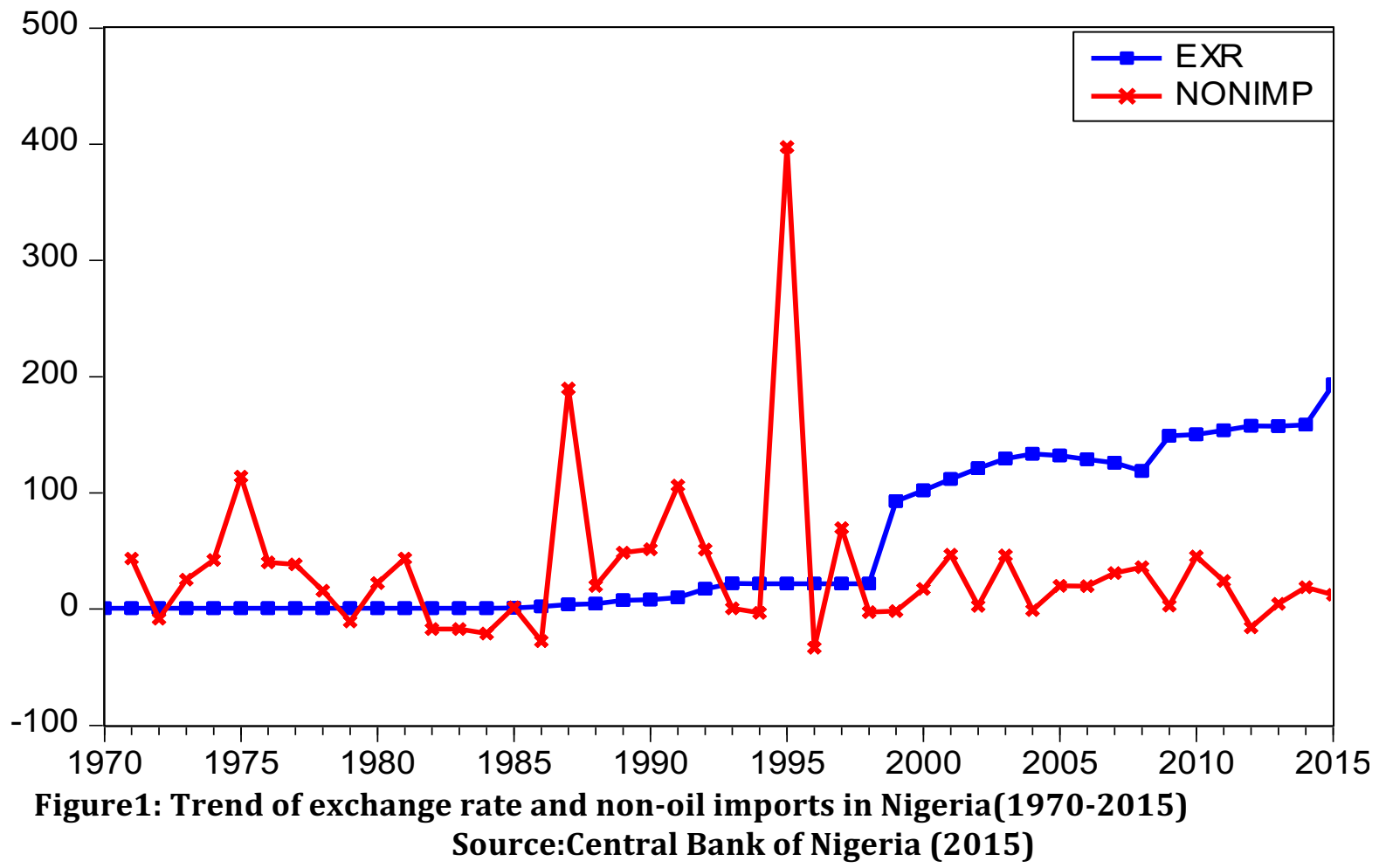

This study is significant to policy makers as it will provide relevant information needed for their work. It will also be quite useful to the government as it will offer information needed for the achievement of exchange rate stability, import management strategies, and economic growth objectives. Furthermore, this study will serve not only as an additional stock of knowledge but it will also serve as a reference material for students and researchers who are interested in this subject matter. The study is organized into five sections. Section 1 is the introduction while section 2 reviews related literature. Section 3 explains in detail the methodology of research while section 4 presents the empirical results and their discussions. Section 5 embodies the summary, conclusions and recommendations of the study.

\section{Theoretical Framework}

\section{LITERATURE REVIEW}

There are several theories on the subject of exchange rate and imports/ exports. However, the theory that is relevant in developing countries like Nigeria is the Marshall Lerner condition (MLC). therefore, this study has as its main theoretical framework, the Marshall Lerner Condition, (MLC).

The Marshall-Lerner condition (also called the Marshall-Lerner-Robinson, hereafter, MLR, condition) is at the heart of the elasticity's approach to the balance of payments. It is named after the three economists who discovered it independently: Alfred Marshall, Abba Lerner and Joan Robinson. The condition seeks to answer the following question: when does a real devaluation (in fixed exchange rates) or a real depreciation (in floating exchange rates) of the currency improve the current account balance of a country?

For simplicity, assume that trade in services, investment-income flows, and unilateral transfers are equal to zero, so that the trade account is equal to the current account. In its simplest version, the MLR condition states that a real devaluation (or a real depreciation) of the currency will improve the trade balance if the sum of the elasticities (in absolute values) of the demand for imports and exports with respect to the real exchange rate is greater than one, $(\varepsilon+$ $\varepsilon^{*}>1$ ). [Note: the real exchange rate is the relative price of foreign goods in terms of domestic 
goods. A real depreciation is equal to a nominal depreciation if the domestic price and the foreign price levels remain unchanged]. The mathematical derivation of the model is thus, The trade balance denominated in domestic currency (with domestic and foreign prices normalized to one) is given by: $N_{x}=x-Q e$

Where, $\mathrm{X}=$ exports and $\mathrm{Q}=$ imports.

e is defined as the price of one unit of foreign currency in terms of the domestic currency.

Differentiating with respect to e gives: $\delta \mathrm{X} / \delta \mathrm{e}=\delta \mathrm{X} / \delta \mathrm{e}-\mathrm{e} \delta \mathrm{Q} / \delta \mathrm{e}-\mathrm{Q}$.

Dividing equation (2) through by $\mathrm{X}$ :

$\delta \mathrm{Nx} / \delta \mathrm{e} .1 / \mathrm{X}=\delta \mathrm{X} / \delta \mathrm{e} \cdot 1 / \mathrm{X}-\mathrm{e} / \mathrm{X} . \delta \mathrm{Q} / \delta \mathrm{e}-\mathrm{Q} / \mathrm{X}$

At equilibrium $\mathrm{X}=\mathrm{eQ}$..........(4), therefore,

$\delta \mathrm{Nx} / \delta \mathrm{e} \cdot 1 / \mathrm{X}=\delta \mathrm{X} / \delta \mathrm{e} \cdot 1 / \mathrm{X}-1 / \mathrm{Q} \cdot \delta \mathrm{Q} / \delta \mathrm{e}-1 / \mathrm{e}$

Multiply through by e:

$\delta \mathrm{Nx} / \delta \mathrm{e} \cdot \mathrm{e} / \mathrm{X}=\delta \mathrm{X} / \delta \mathrm{e} \cdot \mathrm{e} / \mathrm{X}-\delta \mathrm{Q} / \delta \mathrm{e} \cdot \mathrm{e} / \mathrm{Q}-1$

Equation 6 can also be expressed as.

$\delta N x / \delta e . e / X=n X e-n Q e-1$

Where nXe and nQe are common notation for the elasticity of exports and imports with respect to the exchange rate respectively.

In order for a rise in e to have a positive effect on that country's trade balance, the left hand side of the equation must be positive i.e., for a rise in e to cause a rise in nXe.

Therefore, $\mathrm{nXe}-\mathrm{nQe}-1>0$

This theory is very applicable to the Nigerian economy being that the Nigerian economy is import dominated and this has registered its effect on the country's currency. Sometime in the past, the Nigerian effort had put up effort to promote exports and also discourage import by devaluing the country's currency. But has this strategy really been effective for the purpose which it was being carried out? This is the same view presented in the Marshall-Lerner condition. Therefore, to have a logical conclusion, it is important to carry out an empirical analysis of the situation.

\section{Empirical Literature Review}

Tavakoli and Saiah (2010) in their study investigated the effect of currency fluctuations on economic activity of selected developing countries from 1980 to 2009. Exchange rate fluctuations are divided into two groups of expected and unexpected ones and the impact of such fluctuations on the country's economic activity are evaluated besides the two instruments of monetary policy (liquidity) and fiscal policy (government spending). Their results pointed that with the increase in the exchange rate, would show a negative reaction and consumer expenditures show a positive reaction. Imports of real output and private investment do not show a significant effect considering the exchange rate fluctuations.

Duasa (2009) examined the effect of exchange rate shock on Malaysian prices of imports, using monthly data on nominal exchange rates, money supply, prices of imports and exports covering the period of M1:1999 to M12:2006, the study employs the Vector Error Correction Model. For further analysis, an innovation accounting by simulating variance decompositions 
and impulse response functions were adopted. The findings indicate that while the exchange rate shocks significantly affect the fluctuation of import prices, the degree of pass through is incomplete. Genc and Artar (2014) studied the effects of exchange rate on imports and exports of emerging countries. The study applies the panel cointegration method. Data used in this study covered the period from 1985-2012. The annual data used in the empirical analysis were obtained from the World Bank data base. The results revealed that there is cointegrated relationship between effective exchange rates and exports-imports of emerging countries in the longrun.

Dutta and Ahmed (2006) using co integration anderror correction model approaches investigated thebehaviour of Indian aggregate import demandduring the period 1971-1995. The results obtainedindicate that import volume is co integrated withrelative import price and real GDP. The output ofthe econometric model estimate shows that importdemand in India is largely explained by real GDPand generally less sensitive to exchage rate changes. Oyovwi (2012) offered empirical evidence on the impact of real exchange rate volatility on Nigeria's imports. The study employed Augmented Dickey-Fuller (ADF) and co-integration to test stationarity and long-run equilibrium relationship of the variables. Parsimonious error correction mechanism was estimated with the Schwarz Criterion and Akaike information criterion as lag length selection criterion. The result indicated that real exchange rate volatility had no significant effect on Nigeria's imports.

\section{Nature and Sources of Data}

\section{RESEARCH METHODOLOGY}

The study employed secondary data from sources such as: Central Bank of Nigeria (CBN), Statistical Bulletin; Central Bank of Nigeria (CBN) Annual Report Statement of Account; Central Bank of Nigeria (CBN) Economic and Financial Review; and National Bureau of Statistical (NBS). The estimation covered the period between 1970 and 2015.

\section{Model Specification}

The model adopted in this study is drawn from the postulations of the Marshall Lerner condition with some structural modification being that other variables that are considered by theory and other empirical works to be influential to a country's import and export have been added to the original model. Thus, this study specifies the following model:

NOIMP=F(EXR,OPN,MS,INTR,TGE,INF,RGDP)

$$
(-)(+)(+/-)(+)(+/-)(+)(-)
$$

Where:

$$
\begin{aligned}
& \text { NOIMP = Non-oil imports (\%) } \\
& \text { EXR =Exchange rate } \\
& \text { OPN = degree of openness (imports+exports/GDP) } \\
& \text { MS = Money supply }(\%) \\
& \text { INTR = Interest Rate (prime lending rate) } \\
& \text { TGE = Total Government Expenditure (\% of GDP) } \\
& \text { INF = Inflation rate } \\
& \text { GDP = Gross Domestic Output }(\%)
\end{aligned}
$$

\section{Apriori Expectation.}

The signs in the parenthesis represent apriori expectations of each of the variables used in this study. 


\section{Analytical Techniques}

The analytical techniques employed for the purpose of this study are based on the specific objectives of the study.

\section{Objective 1.}

To investigate the long run relationship between exchange rate volatility and non-oil in Nigeria, the Johansen Cointegration and the Error Correction Model techniques were employed.

\section{Cointegration.}

The Johansen test of Cointegration was carried out in this study to determine whether there exists a longrun relationship between exchange rate volatility and imports in Nigeria. Cointegration implies there is some long run equilibrium relationship tying the individual variables together represented by some linear combinations of them.

\section{Error Correction Model.}

The Error Correction model directly estimates the speed at which a dependent variable returns to equilibrium after a change in other variables. The VECM adds error correcting feature to a multi factor model. E.g $\mathrm{Y}=70+0.5 \mathrm{X}_{1}-0.75 \mathrm{ECM}_{-1}$. The coefficient of ECM will show how much value it will take imports to return back to equilibrium after a deviation caused by the volatility in exchange rate.

\section{Objective 2.}

To determine the nature of the causal relationships between exchange rate, non-oil imports and non-oil exports, the Granger causality test was employed.

\section{Granger Causality Test.}

The Granger causality test states that the cost and effect relationship is that the past value should affect the present value. The Granger causality equations for the purpose of this study are specified thus:

$$
\begin{aligned}
& n \quad n
\end{aligned}
$$

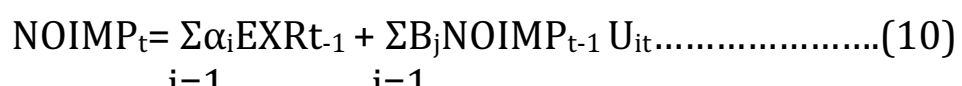

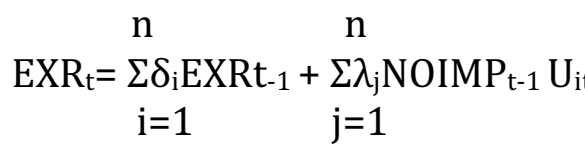

The NOIMP is affected by the past values of EXR and NOIMP, and EXR is equally affected by the past values of NOIMP and EXR. The decision rule is that if $\alpha_{i}=0$, then EXR $\mathrm{E}_{\mathrm{t}-1}$ does not granger cause changes in NOIMP $_{\mathrm{t}-1}$. if $\delta_{\mathrm{j}}=0$ then NOIMP $_{\mathrm{t}-1}$

\section{PRESENTATION OF RESULTS AND DISCUSSIONS}

This section presents the result of the empirical analysis and their interpretations. Time series data covering the period 1970 to 2015 was used for analysis. The empirical results were generated using E-view 7.2 econometrics software.

\section{Unit Root Test Results}

We begin this analysis by examining the time properties of the data. This is done in order to avoid spurious regression. The orders of integration of the variables are examined using the 
Augmented Dickey-Fuller (ADF) and the Phillip-Perron (PP) test statistics. The result of this test is presented in tables $4.1 \mathrm{a}$ and table $4.1 \mathrm{~b}$.

Table 4.1a: Result of Unit Root Test Based On Augmented Dickey Fuller (ADF)

\begin{tabular}{lllll}
\hline Variable & G ADF & $\begin{array}{l}\mathbf{1 \%} \text { critical } \\
\text { value } \mathbf{~}^{* *} \text { ) }\end{array}$ & $\begin{array}{l}\mathbf{5 \%} \text { critical } \\
\text { value }\left(^{*}\right)\end{array}$ & $\begin{array}{l}\text { Order of } \\
\text { integration }\end{array}$ \\
\hline Rgdp & $-6.802^{* *}$ & -4.18 & -3.51 & $\mathrm{I} \sim(1)$ \\
Exr & $-6.140^{* *}$ & -4.18 & -3.51 & $\mathrm{I} \sim(1)$ \\
Inf & $-3.867^{*}$ & -4.18 & -3.51 & $\mathrm{I} \sim(1)$ \\
Intr & $-10.37^{* *}$ & -4.18 & -3.51 & $\mathrm{I} \sim(1)$ \\
Ms & $-4.750^{* *}$ & -4.18 & -3.51 & $\mathrm{I} \sim(1)$ \\
Tge & $-6.956^{* *}$ & -4.18 & -3.51 & $\mathrm{I} \sim(1)$ \\
Inv & $-7.138^{* *}$ & -4.18 & -3.51 & $\mathrm{I} \sim(1)$ \\
Nonimp & $-6.4040^{* *}$ & -4.18 & -3.51 & $\mathrm{I} \sim(1)$ \\
& & & & \\
Opn & $-8.265927^{* *}$ & -4.18 & -3.51 & $\mathrm{I} \sim(1)$ \\
\hline
\end{tabular}

Source: Authors' computation using (EVIEWS 9)

Table 4.1b: Result of Unit Root Test Based On Phillip Perron (PP)

\begin{tabular}{|c|c|c|c|c|}
\hline Variable & $\begin{array}{l}\text { PP adjusted } \\
\text { stat }\end{array}$ & $\begin{array}{l}1 \% \text { critical } \\
\text { value }\left({ }^{* *}\right)\end{array}$ & $\begin{array}{l}5 \% \text { critical } \\
\text { value }(*)\end{array}$ & $\begin{array}{l}\text { Order of } \\
\text { integration }\end{array}$ \\
\hline Rgdp & $-7.181303^{* *}$ & -4.18 & -3.51 & $\mathrm{I} \sim(1)$ \\
\hline Exr & $-6.148566^{* *}$ & -4.18 & -3.51 & $\mathrm{I} \sim(1)$ \\
\hline Inf & $-3.803509^{*}$ & -4.18 & -3.51 & $\mathrm{I} \sim(1)$ \\
\hline Intr & $-10.28^{* *}$ & -4.18 & -3.51 & $\mathrm{I} \sim(2)$ \\
\hline Ms & $-4.804930^{* *}$ & -4.18 & -3.51 & $\mathrm{I} \sim(1)$ \\
\hline Tge & $-6.866505^{* *}$ & -4.18 & -3.51 & $\mathrm{I} \sim(1)$ \\
\hline Inv & $-6.778792^{* *}$ & -4.18 & -3.51 & $\mathrm{I} \sim(1)$ \\
\hline Nonimp & $-5.373461^{* *}$ & -4.18 & -3.51 & $\mathrm{I} \sim(1)$ \\
\hline Opn & $-8.235902^{* *}$ & -4.18 & -3.51 & $\mathrm{I} \sim(1)$ \\
\hline
\end{tabular}

Source: Authors' computation using (EVIEWS 9)

The result of the unit root test for both the Augmented Dickey fuller test and the Phillip Perron test shows that all the variables used in this study are stationary at various levels of integration as shown in the tables $4.1 \mathrm{a}$ and $4.1 \mathrm{~b}$. However, none of the variables were stationary at level. This expression satisfies our choice of carrying out the Johansen test of cointegration.

\section{Cointegration and Error Correction Model Results}




\section{Table 4.2a: Unrestricted Cointegration Rank Test (Trace) Noimp}

\begin{tabular}{lllll}
\hline \hline Hypothesized & & Trace & 0.05 & \\
& & & Critical & \\
No. of CE(s) & Eigenvalue & Statistic & Value & Prob.** \\
& & & & \\
\hline \hline None ${ }^{*}$ & 0.715563 & 218.9978 & 159.5297 & 0.0000 \\
At most 1* & 0.670973 & 164.9364 & 125.6154 & 0.0000 \\
At most 2* & 0.607741 & 117.1369 & 95.75366 & 0.0008 \\
At most 3* & 0.542710 & 76.89606 & 69.81889 & 0.0122 \\
At most 4 & 0.479054 & 43.25128 & 47.85613 & 0.1266 \\
At most 5 & 0.213477 & 15.21061 & 29.79707 & 0.7663 \\
At most 6 & 0.071241 & 4.884896 & 15.49471 & 0.8209 \\
At most 7 & 0.038919 & 1.706936 & 3.841466 & 0.1914 \\
\hline \hline
\end{tabular}

Source: Authors' computation using (EVIEWS 9)

Trace test indicates 4 cointegratingeqn(s) at the 0.05 level

* denotes rejection of the hypothesis at the 0.05 level

**MacKinnon-Haug-Michelis (1999) pvalues

The results of the max Eigen test indicates that at 5\% significance level, there are four cointegrating factors and the trace test indicates that there are three cointegrating factors between exchange rate and non-oil imports. Hence, we reject the null hypothesis. Therefore, there is an existence of a longrun relationship between exchange rate volatility and non-oil imports in Nigeria. Hence the need to estimate the ErrorCorrectionMecahnism (ECM). 
Table 4.2b: Unrestricted Cointegration Rank Test (Maximum Eigenvalue) Noimp

\begin{tabular}{lllll}
\hline \hline \multicolumn{2}{l}{$\begin{array}{l}\text { Hypothesized } \\
\text { No. of CE(s) }\end{array}$} & Eigenvalue & $\begin{array}{l}\text { Max-Eigen } \\
\text { Statistic }\end{array}$ & \multicolumn{2}{l}{$\begin{array}{l}\text { C.05 } \\
\text { Critical Value Prob.** }\end{array}$} \\
\hline \hline None $^{*}$ & 0.715563 & 54.06141 & 52.36261 & 0.0331 \\
At most 1 $^{*}$ & 0.670973 & 47.79945 & 46.23142 & 0.0337 \\
At most 2 & 0.607741 & 40.24086 & 40.07757 & 0.0479 \\
At most 3 & 0.542710 & 33.64478 & 33.87687 & 0.0533 \\
At most 4 & 0.479054 & 28.04067 & 27.58434 & 0.0437 \\
At most 5 & 0.213477 & 10.32571 & 21.13162 & 0.7136 \\
At most 6 & 0.071241 & 3.177959 & 14.26460 & 0.9342 \\
At most 7 & 0.038919 & 1.706936 & 3.841466 & 0.1914 \\
\hline \hline
\end{tabular}

Source: Authors' computation using (EVIEWS 9)

Max-eigenvalue test indicates 3 cointegratingeqn(s) at the 0.05 level

$*$ denotes rejection of the hypothesis at the 0.05 level

**MacKinnon-Haug-Michelis (1999) p-values

Table 4.2c: Cointegrating Regression of Exchange Rate volatility and Non-Oil Imports

\begin{tabular}{lllll}
\hline \hline Variable & Coefficient & Std. Error & t-Statistic & Prob. \\
\hline \hline EXR & 48.53608 & 6.072731 & 7.992464 & 0.0000 \\
INTR & -74.39206 & 51.13354 & -1.454858 & 0.1541 \\
INF & 18.63120 & 17.05047 & 1.092709 & 0.2816 \\
TGE & 8.727832 & 9.733150 & 0.896712 & 0.3757 \\
MS & -24.24385 & 17.57064 & -1.379793 & 0.1759 \\
RDGP & -0.490146 & 3.140455 & -0.156075 & 0.8768 \\
OPN & -120.5862 & 53.42370 & -2.257167 & 0.0300 \\
C & 853.0046 & 810.3410 & 1.052649 & 0.2993 \\
\hline \hline
\end{tabular}

Source: Authors' computation using (EVIEWS 9)

$\begin{array}{llll}\text { R-squared } & 0.798699 & \text { Mean dependent var } 1600.051 \\ \text { Adjusted R-squared } & 0.760615 & \text { S.D. dependent var } & 2645.530 \\ \text { S.E. of regression } & 1294.377 & \text { Sum squared resid } & 61990199 \\ \text { Long-run variance } & 2894755 . & & \end{array}$

The result of the cointegrating regression shows that there is $80 \%$ impact of exchange rate volatility on nonoil imports in Nigeria. The coefficient of exchange rate indicates a $49 \%$ positive relationship, the coefficient of interest rate shows a $74 \%$ negative relationship, the coefficient of inflation shows $18 \%$ positive relationship, TGE expresses $8 \%$ positive relationship, money supply shows $24 \%$ inverse relationship, RGDP shows 0.49 inverse relationship, OPN indicates $120 \%$ inverse relationship with nonoil imports. 
Table 4.2d: ParsimoniousECM Results Of Exchange Rate And Non-0il

Imports

\begin{tabular}{lllll} 
& Coefficient & Std.Error & t-value & t-prob \\
\hline Constant & 31.8165 & 16.62 & 1.91 & $0.064^{*}$ \\
EXR & 0.596504 & 0.5877 & 1.02 & $0.017^{* *}$ \\
INF & -0.0167104 & 0.02881 & -0.580 & $0.066^{*}$ \\
INTR & -1.17963 & 1.084 & -1.09 & $0.084^{*}$ \\
\hline MS & 0.00595658 & 0.03372 & 0.177 & $0.061^{*}$ \\
RDGP & 0.00474085 & 0.003950 & 1.20 & $0.038^{* *}$ \\
TGE & -8.0444132 & 0.0004704 & -0.171 & $0.065^{*}$ \\
OPN & .392811 & 0.2186 & 1.80 & $0.081^{*}$ \\
ECM-1 & -0.575911 & 0.5154 & -1.12 & $0.022^{* *}$ \\
\hline
\end{tabular}

Sigma 55.2761

$\mathrm{R}^{\wedge} 2 \quad 0.760921$

log-likelihood-207.847

no. of observations 42

RSS 48887.1995

$\mathrm{F}(25,16)=2.037[0.071]$

DW 1.92

no. of parameters 26

$-0.00595658 * \mathrm{MS}-0.00474085 * \mathrm{RDGP}+8.04441132 * \mathrm{TGE}-0.392811 * \mathrm{OPN}$

$-0.575911^{*} \mathrm{ECM}_{-1}$

The result of the ECM shows that in the longrun, exchange rate volatility accounts for $76 \%$ of the deviations of non-oil imports from its equilibrium value. However, $57 \%$ of the displacement of non-oil imports from its equilibrium value as a result of the volatility in exchange rate is corrected annually. This indicates that it will take approximately two years for the disequilibrium caused by exchange rate volatility in the trends of non-oil imports to be corrected back to its equilibrium value.

\section{Granger Causality Results}

Table 4.3a: Causality Test of Exchange Rate and Non-Oilimp Pairwise Granger Causality Tests Sample: 19702015

Lags: 3

\begin{tabular}{lccc}
\hline \hline Null Hypothesis: & Obs & F-Statistic & Prob. \\
\hline \hline EXR does not Granger Cause NONIMP & 43 & 2.11807 & 0.1150 \\
NONIMP does not Granger Cause EXR & & 0.58122 & 0.6312 \\
\hline \hline
\end{tabular}

\section{Source: Authors' computation using (EVIEWS 9)}

The granger causality test reveals that there is no causality between exchange rate and non-oil imports in Nigeria. Exchange rate does not granger cause the non-oil imports; this is decided based on their probability values which are not significant. Hence, we accept the null hypothesis.

\section{Policy Implication of Findings}

The cointegration results reveal that there is an existence of a long run relationship between exchange rate volatility and non-oil imports in Nigeria. The policy implication is that the exchange rate can be used as a policy tool to control the inflow of non-oil commodities, but the 
government should also put the necessary infrastructures on ground to promote local production of non-oil products like agricultural, pharmaceuticals, and textile products. Furthermore, the exchange rate should be closely monitored and effectively managed. Specifically, policies that seek to maintain the exchange rate at a very minimal level should be promoted. The government and relevant monetary authorities should seek to employ and implement policies that stabilize the exchange rate given its significant impact on non-oil imports in Nigeria.

The result of the cointegrating regression of exchange rate and non-oil imports showed that there is $80 \%$ impact of exchange rate on non-oil imports in Nigeria. The coefficient of exchange rate indicates a $49 \%$ positive relationship, the coefficient of interest rate shows a $74 \%$ negative relationship, the coefficient of inflation shows 18\% positive relationship, TGE expresses $8 \%$ positive relationship, money supply shows $24 \%$ inverse relationship, RGDP shows 0.49 inverse relationship, OPN indicates $120 \%$ inverse relationship with non-oil imports. The result of the ECM shows that $57 \%$ of the displacement of non-oil imports from its equilibrium value as a result of the volatility in exchange rate is corrected annually. The granger causality test reveals that there is no causality between exchange rate and non-oil imports in Nigeria.

\section{SUMMARY, POLICY RECOMMENDATIONS AND CONCLUSION}

This paper sought to analyse the relationship between exchange rate volatility and non-oil imports in Nigeria using annual data covering the period of 1970 to 2015. Specifically, it sought to: investigate the existence of a long run relationship between exchange rate volatility and non-oil imports in Nigeria; and determine the nature of the causal relationships between exchange rate volatility and non-oil imports in Nigeria. The study employed the Johansen test of Cointegration, Error Correction Model, and the Granger Causality test to achieve the objectives.

The findings reveal that: there exists a long run relationship between exchange rate volatility and non-oil import,; exchange rate does not granger cause the movements in non-oil imports. The study recommends amongst others that the exchange rate should be closely monitored and effectively managed. Specifically, policies that seek to maintain the exchange rate at a very minimal level should be promoted. The government and relevant monetary authorities should seek to employ and implement policies that stabilize the exchange rate given its significant impact on non-oil imports in Nigeria.

This study has revealed the critical role that exchange rate plays in a country's economy given its long run relationship with non-oil imports. Thus, exchange rate is not only an important price in the economy but could also be seen and used as an effective policy tool which the government can employ to achieve its varied objectives.

\section{References}

Adeoye, B.A and Atanda, A.A (2010). Exchange Rate Volatility in Nigeria: Consistency, Persistency and Severity Analyses. CBN Journal of Applied Statistics, 2(2): 29-49

Ahmad, H.I and Zarma, A.B (1997). The Impact of Parallel Market on theStability of Exchange Rate: Evidence from Nigeria. NDIC Quarterly,7(2): 42-61.

Central Bank of Nigeria (2015) Statistical Bulletin, Central Bank of Nigeria, Abuja.

Dutta, D.and Ahmed, N. (2006). “An Aggregate Import Demand Function Of Bangladesh: A Cointegration Approach". Applied Economics, 31: 465-72.

Duasa (2009). Exchange Rate Shock On Malaysian Prices Of Imports And Exports: An Empirical Analysis, Journal of Economic cooperation and Development, 30, 3; 2009, pp 99-114, Malaysia 
Genc, E. F. and Artar, O. K. (2014). The Effect Of Exchange Rates On Export And Imports Of Emerging Countries. European Scientific Journal, 13: 1857-7881., Istanbul Commerce University, Istanbul.

Olisadebe, E.U.(1991). Appraisal of Recent Exchange Rate Policy Measures in Nigeria. CBN Economic and Financial Review, 29(2).

Oyovwi, O.D. (2012). "Exchange rate Volatility and Imports in Nigeria”. Academic journal of Interdisciplinary Studies, Vol 1(2): 103-114.

Tavakoli, A. and Saiah, M. (2010). The Effect Of Exchange Rate Fluctuations On Economic Activities. Journal of Economics and Monetary, 2(4), 59-77. 